\title{
THE BUSINESS CONTINUITY CONCEPT IN THE ASSESSMENT OF CREDITWORTHINESS OF ECONOMICAGENTS
}
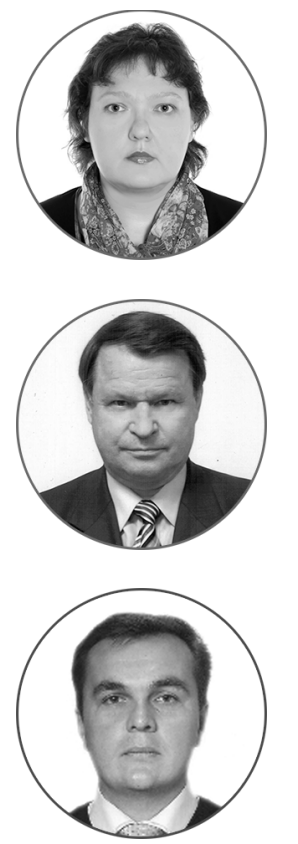

\section{Article history:}

Received 2 October 2017

Received in revised form 6 October 2017

Accepted 12 October 2017

Translated 12 January 2018

Available online 27 March 2018

JEL classification: 012, 001

Keywords: business continuity management, BCM, going concern, creditworthiness, sustainable development

\author{
Nadezhda E. BABICHEVA
}

Voronezh State University, Voronezh, Russian Federation

sigaeva@mail.ru

Corresponding author

Nikolai P. LYUBUSHIN

Voronezh State University, Voronezh, Russian Federation

lubushinnp@mail.ru

\section{Roman Yu. KONDRAT'EV}

Lipetsk Branch of Financial University under Government of Russian Federation, Lipetsk, Russian Federation

romario_80@inbox.ru

\begin{abstract}
Importance The article analyzes the existing contradictions in the implementation of the going concern principle and securing the creditworthiness.

Objectives The article presents our original comprehensive study of the business continuity concept in relation to creditworthiness of economic agents to synthesize two accounting concepts, i.e. the dynamic and static balance sheet.

Methods We employ general scientific principles and research methods, namely, a historical approach, analysis and synthesis, induction and deduction, grouping, comparison, abstraction, generalization, and analogy.

Results The paper proves the hypothesis that entity's creditworthiness is a complex accounting and analytical characteristic reflecting the continuity of operations. If the entity does not ensure its creditworthiness, it puts its business continuity at peril. Poor financial solvency leads to bankruptcy, and the economic entity may cease its operations.

Conclusions and Relevance The existing contradictions in the business continuity and creditworthiness assessment appeared in the 19th century. We suggest that the theory and practice of accounting and economic analysis should be developed by synthesizing both accounting concepts of dynamic and static balance sheet through integrated reporting. This will create an information pool to assess the entity's creditworthiness and solvency and subsequently identify and avert the continuity threat.
\end{abstract}

(c) Publishing house FINANCE and CREDIT, 2017

The editor-in-charge of this article was Irina M. Vechkanova

Authorized translation by Irina M. Vechkanova

Please cite this article as: Babicheva N.E., Lyubushin N.P., Kondrat'ev R.Yu. The Business Continuity Concept in the Assessment of Creditworthiness of Economic Agents. Digest Finance, 2018, vol. 23, iss. 1, pp. 3-15. 
Continuous and sustainable extended reproduction depends on the availability of working assets in the entity. The extended reproduction process is interpreted through the following transformation chain: ... money $\rightarrow$ inventories $\rightarrow$ settlements (amounts due) $\rightarrow$ money... If some external and internal factors disrupt the chain in a certain point, the reproduction process is discontinued as well, thus causing breaches in the going concern principle, loss of financial sustainability and corporate crisis. L.A. Mendel'son concludes that many bourgeois economists tend to evaluate the severity of crises by their effects on distribution. Bankruptcy, bank smash, dropping prices and their implications are aspects that those economist focus on, first of all. From the individual capitalists' perspectives, this approach is quite understandable. Profit margin, prices, loss of their creditworthiness determine their wealth, don't they? To adequately evaluate the crisis, its severity, it is necessary to consider its multiple forms in each aspect of economy, including lending [1, p. 205].

To ensure the continuing production process, the owner shall have net working capital, the share of which shapes the balance structure. The share is calculated as the ratio of net working assets to total current assets ${ }^{1}$. This indicator is viewed as a source for finance of current assets, being an underlying element of liquidity ratios banks consider to evaluate borrowers' creditworthiness. This is mentioned by many researchers, such as V.V. Kovalev, E. Al'tman, R. Chelik et al. [2, pp. 486-488, 3, 4].

On the one hand, if the entity has no net working capital, it has to utilize borrowed sources of finance in order to observe the going concern principle. According to V.V. Kovalev, creditors in the balance sheet usually imply that the entity has an additional source of finance. That is, the entity may utilize the creditor's funds for some time, which shall ultimately be returned and accounts payable shall be repaid at a certain moment of time ${ }^{2}$. On the other hand, according to

${ }^{\dagger}$ For the source article, please refer to: Бабичева Н.Э., Любушин Н.П., Кондратьев Р.Ю. Концепция непрерывности деятельности в оценке кредитоспособности экономических субъектов. Экономический анализ: теория и практика. 2017. Т. 16. № 10. C. 1840-1858. URL: https://doi.org/10.24891/ea.16.10.1840

${ }^{1}$ Net working capital shall mean working assets less current liabilities or a part of equity used to finance working assets.

${ }^{2}$ Kovalev V.V., Kovalev Vit.V. Korporativenye finansy i uchet: ponyatiya, algoritmy, pokazateli [Corporate finance and accounting: Concepts,
A.E. Shevelev, B.A. Amanzholova, N.N. Ovchinninkova $[5,6]$, unavailability of net working assets, incompliance with advisable solvency and creditworthiness indicators signify the entity's financial problems, being a serious reason for auditors and creditors to doubt the entity's ability to continue as a going concern. The above reasoning proves that there are contradictions in evaluating whether the entity is still a going concern and able to repay. Further studies are required in this respect.

Numerous approaches to creditworthiness evaluation were presented in researches led by D.A. Endovitskii. We adhere to the definition given in the monograph referred to in [7, p. 174] stating that the borrower's creditworthiness (the entity) shall mean a comprehensive legal and economic characteristic embodied through financial and non-financial indicators. It helps evaluate whether the borrower (entity) is able to fulfill its debt obligations to the creditor in the future and within timelines stipulated in the loan agreement. It is also the basis to assess the risk associated with a certain borrower. In addition to financial characteristics of the borrower, this definition of creditworthiness involves legal ones (legal capacity, business reputation) and emphasizes the legitimacy and necessity of considering non-financial indication for analysis purposes.

As said in the research referred to herein [8], liquidity, working capital-to-current assets ratio come into the spotlight as The Law of the Russian Federation On Insolvency (Bankruptcy) in the 1992 edition pronounces the ability to repay debts as a solvency criterion. The entity is deemed insolvent if its accounts payable exceed the property value. As the law was further enforced, the Russian Government adopted Resolution No. 498 On Some Actions for Enforcement of Insolvency (Bankruptcy) Law (edition of October 3, 2002) promulgating two financial ratios:

- current liquidity ratio $k^{\text {cur.ldt }}$, with the statutory value of $k^{\text {cur.ldt }} \geq 2$;

- working capital-to-current assets ratio $k^{\text {fin.sust }}$, with the statutory value of $k^{\text {fin.sust }}>0.1$.

Fig. 1 shows trends in the current ratio and working capital-to-current assets ratio.

algorithms, indicators]. Moscow, Prospekt, KnoRus Publ., 2010, p. 280. 
Considering the outcome of the ratios trend and forecast evaluation in Fig. 1, the Russian economy is debt laden because the working capital-to-current assets ratio has been negative since 1996 . The ratios has been far from their statutory values for a long period of time, thus proving the inadequacy of the regulatory framework effective in the 1990s and inapplicability of the said statutory values of the ability to repay debts to the current conditions of the Russian economy and, subsequently undermining the going concern principle.

The current ratio reflects the entity's ability to fulfill current liabilities using its current assets, being very popular in foreign analytical practices. As the analysis by V.N. Edronova and S.Yu. Khasyanova shows [9] the Russian law-makers adopted too high statutory value of the current liquidity in 1994 (Table 1).

If we calculate the average statistic of the current ratio, it will be 1.16 for Russia and approximate the average statistics for Japan, though the use of current assets in business processes substantially differs in Russia and Japan. Japan remains the only country in the world that managed to completely integrate the Just-in-Time system into business processes.

Considering the imperfect regulatory framework for steering and organizational procedure of bankruptcy, which caused the bankruptcy of the Russian major enterprises, law-makers had to adopt new editions of the Federal Law On Insolvency (Bankruptcy) in 1998, 2002 and alter the bankruptcy criteria to the inability to pay. The unsatisfactory structure of balance and its recognition as such cease to have legal implications, being used by credit institutions for reference purposes in deciding on the financial position of borrowers. The current ability to pay has been regarded as a metric of the entity's insolvency since 1998. It is construed as an ability to satisfy creditors' monetary claims (or) make obligatory payments within three months from the date when they are to be made ${ }^{3}$.

However, many publications still describe the insolvency evaluation with reference to liquidity and use indicators set forth in Resolution of the RF Government № 498. This has its own background. Methodological guidelines of the Russian State Statistics Service

\footnotetext{
${ }^{3}$ Federal Law On Insolvency (Bankruptcy) of October 26, 2002 № 127-Ф3 (Edition of July 29, 2017)
}

(Rosstat) $^{4}$ do not include the current solvency indicator. Thus, to evaluate the solvency, current ratio and working capital-to-current assets ratio are used. For example, in the book Finance of Russia. $2016^{5}$, paragraph 3.15 refers to the current ratio, working capital-to-total assets ratio, and equity-to-total assets ratio as solvency and financial sustainability metrics. In our publications, we reiterated that the current ratio and working capitalto-current assets ratio describe the entity's ability to pay. They constituted insolvency criteria before 1998 [8].

The crisis situation with VIM-Avia Airlines aggravated issues associated with corporate financial position evaluation. As stipulated in paragraph 17 of the methodological guidelines of the Russian Ministry of Transport, the current ratio is the most frequent metric to reveal a bankruptcy threat ${ }^{6}$. It reaffirms the inadequacy of institutional regulation on the creditworthiness in various activities in Russia.

There has not been any reduction in numbers of unprofitable entities for the period of reforms (about 30 percent nationwide). According to the Central Bank of Russia, unprofitable entities in the real economy accounted for 34.2 percent in Q1 20177. Naturally, under such circumstances, the primary goal is to ensure the going concern principle and increase the creditworthiness of economic entities.

In this respect, we hypothesize that corporate creditworthiness is a comprehensive accounting and analytical characteristic reflecting the going concern principle. If the entity is not creditworthy, the going concern principle is at stake. The ability to pay is a constraint on the going concern principle and creditworthiness, which, if lost, may cause their bankruptcy and discontinuing of their operations.

\footnotetext{
${ }^{4}$ Methodological Guidelines for Analyzing Financial and Business Operations of Entities, as approved by the Russian State Statistics Service as of November 28, 2002.

${ }^{5}$ Finansy Rossii. 2016: stat. sb [Finance of Russia. 2016: Statistical Yearbook]. Moscow, Rosstat Publ., 2016, 343 p.

URL: http://www.gks.ru/free_doc/doc_2016/fin16.pdf

${ }^{6}$ Methodological Guidelines for Evaluating the Financial and Business Position of Legal Entities Applied to Civil Aviation Authorities for an Air Operator's Certificate for commercial purposes, and legal entities, which already hold such a certificate: instruction of the RF Ministry of Transport of May 5, 2012 № ИЛ-62-p (Edition of July 27, 2016).

${ }^{7}$ Doklad o denezhno-kreditnoi politike [Monetary policy report]. URL: http://www.cbr.ru/publ/ddcp/2017_02_ddcp.pdf (In Russ.)
} 
As G.B. Kleiner points out, the performance of economy, i.e. processes of production, distribution, exchange and consumption of tangibles and intangibles, is viewed through the lens of creating, coordinating, transforming and dissolving economic systems. The undisrupted existence of an entity (and operational environment) contributes to the continuity of time [10, p. 21]. Therefore, laws of system operations imply the continuity of the economic system. Operational distinctions of the economic actor determines the efficiency of the accounting and analytical framework. The accounting and analytical system is based on a structural approach discerning an entity as a complex unit, which consists of several subsystems. In the subsystems, accounting and analytical processes are irreversible and predetermined, unlike simple systems in classical physics. It is impossible to predict and foresee how this accounting system will behave within protracted periods of time.

Let us refer to G.B. Kleiner's researches assuming that, once originated, an economic system generally carries on continuously and survives all interim points of time, from its inception to its dissolution. Thus the period of the economic system shall represent the interval $<a$, b $>$ on the number line of time $-\infty \leq a, b \leq \infty$. The bounds of this interval become indefinite, if one or both integers $a, b$ are unknown or equal $-\infty$ or $+\infty$. Notwithstanding that the life cycle of a certain entity or life expectancy of a person are finite, business customs and community life rely upon the assumption that the operating entity and human life are perpetual [10, p. 14].

Being a common concept in philosophy and law of metaphysics and logic, the continuity principle was corroborated and unfolded in proceedings by G.W.F. Hegel ${ }^{8}$, I. Kant ${ }^{9}$, G.W. Leibnitz ${ }^{10}$, C.S. Peirce ${ }^{11}$, E. Schrödinger ${ }^{12}$ and other scholars. C.A. Peirce

\footnotetext{
${ }^{8}$ Hegel G.W.F. Nauka logiki: v 3 t. Tom 1 [Wissenschaft der Logik. Buch 1]. Moscow, Mysl' Publ., 1970, 590 p.

${ }^{9}$ Kant I. Sochineniya: $v 6 t$. Tom 1 [Works. Six Volumes. Volume 1]. Moscow, Mysl' Publ., 1963, 543 p.

${ }^{10}$ Leibniz G.W. Sochineniya: v 4 t. Tom 3 [Works. Four Volumes. Volume 3]. Moscow, Mysl' Publ., 1984, 734 p.

${ }^{11}$ Peirce C.S. Printsipy filosofii: $v 2 t$ [Russian edition. Principles of philosophy. Two volumes]. St. Petersburg, Saint Petersburg Philosophic Society Publ., 2001, 224 p.

${ }^{12}$ Schrödinger E. Izbrannye trudy po kvantovoi mekhanike [Russian edition. Selected works on quantum mechanics]. Moscow, Nauka Publ., $1976,422 \mathrm{p}$.
}

emphasizes the importance of this principle, now continuity, it is not too much to say, is the leading conception of science. The complexity of the conception of continuity is so great as to render it important wherever it occurs. Now it enters into every fundamental and exact law of physics or of psychics that is known. ...It seem not unlikely that if the veritable laws were known continuity would be found to be involved in them ${ }^{13}$.

In management, accounting and analytical science scholars single out the business continuity concept and going concern principle. As a rule, this concept implies a system of views concerning the given aspect or phenomenon, while principles mean the fundamental framework underlying theoretical and practical activities. In the Russian language, the business continuity concept and going concern principle semantically convey the same meaning, while they are not synonyms in English. For example, the going concern principle is understood as the entity's possibility (concern) of continuing its operations within a foreseeable period of time, without going bankrupt or becoming insolvent ${ }^{14}$. Business continuity management constitutes the management process identifying potential threats to the entity's business operations. This process is the basis for corporate sustainability to effectively protect interest of its key stakeholders, reputation, brand and value creation ${ }^{15}$. In the Russian practice, corporate sustainability activities are attributed to crisis management, thus restricting the interpretation of this principle in accounting and auditing. This may be due to the fact that issues of the Russian entities' escalated in the early 1990s, when the centrally planned economy was abolished, and were attributed to managerial tasks.

Business continuity management researches gained traction in the late 20th century in proceedings by scholars from Great Britain, USA, Japan, Australia and

\footnotetext{
${ }^{13}$ Peirce C.S. Printsipy filosofii: $v 2 t$ [Russian edition. Principles of philosophy. Two volumes]. St. Petersburg, Saint Petersburg Philosophic Society Publ., 2001, 224 p.

${ }^{14}$ Accounting Standards Update 2014-15 Presentation of Financial Statements - Going Concern (Subtopic 205-40). Disclosure of Uncertainties about an Entity's Ability to Continue as a Going Concern (An Amendment of the FASB Accounting Standards Codification ${ }^{\circledR}$, August 2014). URL: http://www.fasb.org/resources/ccurl/599/128/ASU \%202014-15.pdf

${ }^{15}$ GOST P 53647.1-2009 Business Continuity Management. Part 1. Practical Guide: Order of the Federal Agency on Technical Regulating and Metrology of December 15, 2009 № 998-ст.
} 
other developed nations. Nowadays, they are an important discipline of strategic management, which links various business processes and economic activities. According to Lyndon Bird, Technical Director of the Business Continuity Institute, business continuity management is the only discipline of management which helps build a high protection wall and sustainability of an entity. However, it is inseparable of security issues, management and communications in emergency and crisis situations ${ }^{16}$.

Issues of business creditworthiness and continuity draw much attention of actors from financial markets. To evidence this, the Financial Stability Forum and Bank of England organized a business continuity symposium in summer 2004. As the symposium follow-up, the Joint Forum working group was set up uniting representatives of the Basel Committee on Banking Supervision, International Organisation of Securities Commissions, International Association of Insurance Supervisors. The resultant guiding principles were released in December 2005 taking the form of the consultation document called High-Level Principles for Business Continuity. This document is intended to support the stability of the global financial system. Although the Joint Forum addressed issues of critically important actors of the financial market, first of all, the principles mentioned below and creditworthiness issues (Principles 2, 3, 5, 7) can be applicable to any economic agent (Table 2).

The regulatory and legal framework for the business continuity concept is set forth in national standards on management in various countries. In Russia, this concept is scrutinized in the national standards of Russia (GOST standards), which are identical to the national standards of the United Kingdom ${ }^{17}$. As per GOST P53647.1-2009. Business Continuity Management. Part. $1^{18}$, business continuity shall mean the strategic and tactic ability of the entity to plan its operations in

\footnotetext{
${ }^{16}$ Petrenko S.A., Belyaev A.V. Upravlenie nepreryvnost'yu biznesa. Vash biznes budet prodolzhat'sya. Informatsionnye tekhnologii dlya inzhenerov [Business continuity management. Your business will go on. IT for engineers]. Moscow, DMK Press, Kompaniya AiTi Publ., 2011, 400 p.

${ }^{17}$ For example, GOST P 53647.1-2009. Business Continuity Management. Part 1. Practical Guide is identical to the national standard of Great Britain BS 25999-1:2006 Business Continuity Management. Part 1: Code of Practice. GOST P53647.1-2009 consists of three parts.

${ }^{18}$ Ibid.
}

case of incidents and its breaches if viewed through the system of processes designated for producing goods, work and services and ensuring the continuity of business practices at the tolerable level. Such processes, which are based on the business continuity concept, include the accounting and controlling system that govern accounting and analytical processes, and information and telecommunication technologies, thus proving that the business continuity concept is the cornerstone of the corporate accounting process.

In Russia, Accounting Concepts in the Market Economy of Russia is the first regulatory document on accounting, which pronounces business continuity as the accounting basis. Business continuity is put there as an assumption that the entity will continue as a going concern in the foreseeable future, and has no intentions and need to wind up or reduce its operations. Therefore, liabilities will be performed in a due manner, thus contributing to the primary purpose of accounting, i.e. the compilation of information on the financial position, financial results and changes in the financial position of the entity, which many interested users need for decision making ${ }^{19}$.

Afterward The Regulation on Accounting and Financial Reporting in the Russian Federation was adopted. It required entities to formulate accounting policies in accordance with the business entity convention, going concern principle, consistency of accounting policies and temporary determination of business facts and other distinctions in business operations ${ }^{20}$.

As per paragraph 77 of the Conceptual Principles of Accounting and Financial Reporting ${ }^{21}$, business continuity is viewed as an assumption that the accounting entity (reporting entity) will continue its operations, perform its rights (functions) and obligations within at least four years starting from

\footnotetext{
${ }^{19}$ Accounting Concept in the Market Economy of Russia was approved by the Methodological Board for Accounting under the RF Ministry of Finance, Presidential Board of the Institute of Professional Accountants of the Russian Federation, as of December 29, 1997.

${ }^{20}$ Order of the RF Ministry of Finance On Approval of the Accounting and Financial Reporting Regulation in the Russian Federation, July 29, 1998 № 34H.

${ }^{21}$ Order of the RF Ministry of Finance On Approval of the Federal Accounting Standard for Public Entities - Conceptual Principles of Accounting and Financial Reporting for Public Entities, of December 31, 2016 № 256H.
}

Please cite this article as: Babicheva N.E., Lyubushin N.P., Kondrat'ev R.Yu. The Business Continuity Concept in the Assessment of Creditworthiness of Economic Agents. Digest Finance, 2018, vol. 23, iss. 1, pp. 3-15. 
the year of its last financial statements (hereinafter referred to as the foreseeable future), and the owner (founder) has no intentions and (or) needs to dissolve the accounting entity (reporting entity) or wind up its operations in the foreseeable future. As per paragraph 5 of Russian Accounting Standards (PBU) 1/2008, accounting policies shall be based on the assumption that the entity will remain a going concern in the foreseeable future and has no intentions and (or) needs to discontinue or significantly reduce its operations. Hence, liabilities will be duly performed (going concern assumption). The management usually states in the explanatory note that the going concern assumption underlies financial statements.

The entity's ability to continue as a going concern laid the basis for an international standard on auditing. ISA 570 Going Concern ${ }^{22}$ states that the going concern principle is fundamental for financial reporting. Thus, auditors must verify that financial statements are compliant with this principle notwithstanding requirements of standards, local or institutional laws, etc. As per paragraph 14 of the Federal Standards on Auditing $^{23}$, auditors shall analyze assessments the auditee's management makes with respect to the entity's ability to continue as a going concern within at least 12 months following the reporting period. Table 3 collates business continuity requirements of the Russian and international standards on accounting and auditing.

Analyzing the data in Table 3, we conclude that requirements to the relevance of the going concern assumption are based on the static balance sheet concept and conditions for ensuring the ability to pay.

The number of studies into this principle significantly increased as a result of global economic crises and accounting scandals [11]. Foreign scholars consider the going concern principle as an accounting fundamental, urging to develop techniques for evaluating and analyzing going concern factors [12-14].

\footnotetext{
${ }^{22}$ International Standard on Auditing 570 (revised) Going Concern was enacted with Order of the RF Ministry of Finance of November 11, 2016 № 207H.

${ }^{23}$ Standard No.11 - Applicability of the Going Concern Assumption to the Audited Entity, as approved by Resolution of the RF Government of September 23, 2002 № 696.
}

However, I.N. Dmitrienko, I.N. Belousova refute the novelty of the going concern assumption and refer to representatives of accounting schools. The first mention of the going concern principle was found in proceedings by Adolphe Guilbault, Eugene Leautey (1860). They illustrate this with the entity that has the financial result on an ongoing basis at any point of time ${ }^{24}$. The business continuity concept was further unveiled by H.V. Simon (1861) in his monograph on the balance sheet studies, which substantiate the legal nature of the static accounting theory based on the continuity statics. The static accounting theory contravened the rule, then in force, for evaluating the entity's ability to fulfill its obligations only in case of its dissolution since the static accounting theory required property items and liabilities be concurrently measured to be reported in the static balance sheet [15, 16].

The term continuing is also discussed as part of one of the definitions of bookkeeping coined by Bonneau, a representative of the French accounting stream. He opined that accounting is a science of orderly recording of continuing movements of various items driving the exchange or transformation (production) so that users can easily understand, in their totality, how they mutually correlate, and third parties' accounts or each account, in particular ${ }^{25}$.

We believe that this definition is a dialectical approach to the nature of accounting. That is, notwithstanding the continuing movement of items (agents), the accounting process may still be disrupted. It may well be influenced by Marx's works. However, the continuity principle was crystallized in 1961 in proceedings of M. Munitz and R. Sprouse,

\footnotetext{
${ }^{24}$ I.N.Dmitrienko and I.N. Belousova studied the definition business continuity from three perspectives, i.e. syntactical, sematic and pragmatic, adhering to the logic-linguistical approach of E.S. Hendriksen and M.F. Van Breda.

${ }^{25}$ Eternal and continuous motion underlies such dialectical laws as the law of unity and struggle of opposites and transformation of quantity into quality. The continuity concept is studied in various scientific disciplines. For example, quantum physics,... large discontinuous and erratic changes occurred in the bacterium, we could not then trace its identity with the passage of time. The continuity also insures that the bacterium will "stay put" long enough to allow it to be seen and recognized. That is, even if it is changing, the effect of changes can always be made arbitrarily small by choosing a sufficiently small interval of time in which to observe it (Bohm D. Kvantovaya teoriya [Quantum Theory]. Moscow, Nauka Publ., 1965, 729 p.).
} 
representatives of the Anglo-American school of accounting ${ }^{26}$. However, its inception is attributed to the 1930s, when the first collective attempts were made in order to establish the unified accounting principles in the USA [15]. Ya.V. Sokolov's studies confirm that the continuity principle shall be examined further and qualified as systemic. Eight of nine sources mention the continuity principle among other accounting ones ${ }^{27}$.

Ya.V. Sokolov compares the continuity principle with the first law of mechanics and states that it facilitates the effective computation of financial results and eliminates senseless attempts to remeasure accountable items. Why shall the entity's assets be remeasured if it is supposed to live forever? On the contrary, if the entity is dissolved, its assets shall be measured at the current market value, rather than their historical cost. Moreover, relying upon the going concern assumption, we can treat the reporting year only as if it relates to the business cycle distinctions, without being pegged to the calendar year. Each sector of economy has its own cycle. Thus, every management, owners are entitled to determine the length of a business year for themselves and their company.

Furthermore, continuity implies that the accounting methodology, valuation and carried forward balances are consistently preserved. Enders, Whitefield and Maure built the requirements into balance sheet principles. The most important thing is that the continuity principle enables the entity to circumvent the preparation of the balance sheet in case of the ownership changes ${ }^{28}$.

Starting from the 1980s, the going concern assumption became a systemic principle of accounting in such countries, as the USA, Great Britain, Germany, etc. [15-17]. According to I.N. Dmitrenko, I.N. Belousova, the continuity principle was included into the generally accepted accounting principles in order to support the profit measurement theory and use the historical cost (cost) instead of the disposal value [15].

\footnotetext{
${ }^{26}$ Sokolov Ya.V. Bukhgalterskii uchet: ot istokov do nashikh dnei [Accounting: From the inception to present days]. Moscow, YUNITI Publ. $1996,638 \mathrm{p}$.

${ }^{27}$ Sokolov Ya.V. Bukhgalterskii uchet: ot istokov do nashikh dnei [Accounting: From the inception to present days]. Moscow, YUNITI Publ., $1996,638 \mathrm{p}$.

${ }^{28}$ Ibid.
}

As F.Kh. Doronina puts it, the business continuity principle is a key concept of the accounting theory and practice in the world. Information based on the continuity principle and presented in financial statements is very important for investors to evaluate their investment in a certain economic agent [18]. Financial statements shall indicate breaches in the continuity principle, such as a significant reduction in production, banks' loan rejection in case of customers' breaches, suppliers' denial of a grace period, and unavailability of additional loans to offset financial deficiency of the entity. It reflects the creditworthiness and solvency of the entity.

In Gestion de L'entreprise et comptabilité (1975), Lexique de comptabilité (1990), P. Lasseque mentioned that it is necessary to give account of factors undermining the loss of creditworthiness and causing the bankruptcy. During 1914-1960, when giant corporations came out, and many economies were submerging into a crisis, statisticians recorded multiple instances of bankruptcy and discontinued operations of small and middle-sized entities. Creditors and owners had to compile accounting information and analyze solvency, liquidity, creditworthiness of respective entities $^{29}$. One hundred years later creditors still do need proper and reliable sources of information about solvency and creditworthiness of economic agents. This information grew even more important as new forms of capital flows and institutions appear. In this respect, N.A. Breslavtseva, I.N. Bogataya state that balance sheet accounts remain the only reliable sources of information for decision making purposes and need to be constantly improved for better use $\mathrm{s}^{30}$.

The content of financial statements depends on purposes and objectives of users, national policy for accounting and control, and operating environment, in which the entity works and develops. The owner analyzes financial results of the respective entity in order to secure more capital. In its fiscal pursuits, the State imposes legal requirements in various disciplines of law, accounting and taxation. Creditors seeking the repayment will consider accounting data and the statement of financial results to assess the debtor's ability to pay/repay the debt and overall financial position.

\footnotetext{
${ }^{29}$ Ibid.

${ }^{30}$ Balansovedenie [Balance sheet studies]. Rostov-on-Don, Feniks Publ., 2004, 475 p.
} 
In Le parfait négociant (1675), Jacques Savary was the first who suggested preparing the balance sheet in line with its purpose ${ }^{31}$. The static balance sheet concept is believed to originate due to insolvency of entities. It is intended to protect the creditor's interests. That is why in the balance sheet shall itemize accounts payable, first of all. However, scientific literature often states that the borrower's creditworthiness is evaluated to assess the balance liquidity (assets), thus making the creditworthiness evaluation focus primitive.

Eugen Schmalenbach, the author of the dynamic balance sheet concept, proved the incompatibility of the two accounting concepts since the dynamic one stems from the business continuity principle, while the static one deals with the discontinued operation principle (Table 4). That is, the dynamic balance sheet is supposed for owners' interests, while the static one is useful for creditors [19, p. 416-419]. It fuels contradictions in enforcing the business continuity principle and ensuring the creditworthiness. However, scholars tried to synthesize both accounting theories in the 19-20th centuries, but this attempt led to nothing (E. Schmalenbach, F. Schmidt, A.P. Rudanovsky) [20, 21].
Hence, we conclude that the existing contradictions in evaluating the business continuity and creditworthiness date back to the 19th century, stemming from two opposite accounting concepts of the static and dynamic balance sheet. The dynamic balance sheet reflects the business continuity concept, while the static one conveys the discontinued operation concept that rests upon the creditworthiness of economic agents. It verifies our hypothesis stating that the entity's creditworthiness is a comprehensive accounting and analytical metric that embodies business continuity. If creditworthiness is not ensured, this may put the borrower's business continuity at peril since solvency is a constraint on the business continuity principle and, subsequently, creditworthiness. Insolvency may cause entities to go bankrupt and discontinue their operations.

Thus, the theory and practice of accounting and economic analysis shall synthesize accounting concepts through integrated financial reporting. This will create an information pool to assess the entity's creditworthiness and solvency and subsequently identify and avert the continuity threat.

\footnotetext{
${ }^{31}$ Zabbarova O.A. Balansovedenie [Balance sheet studies]. Moscow, KnoRus Publ., 2007, 256 p.
} 
Table 1

Values of current ratio in different countries

\begin{tabular}{lllll}
\hline Industry & USA & United Kingdom & EU & Japan \\
\hline Light industry & 2.5 & 1.75 & 1.8 & 1.75 \\
\hline Food industry & 1.2 & 1.2 & 1.4 & 1.3 \\
\hline Machine building & 1.1 & 1.1 & 1.5 & 1.1 \\
\hline Trade & 1.7 & 1.4 & 1 & 1.1 \\
\hline Average & 1.3 & 1.2 & 1.2 & 1.15 \\
\hline
\end{tabular}

Source: $[9]$

Table 2

Definitions and guidelines for business continuity management

\begin{tabular}{ll}
\hline Definitions and principles & Contents \\
\hline Business continuity & $\begin{array}{l}\text { Strategic and tactic ability of the entity to plan its performance in case of incidents and disruptions in order to ensure } \\
\text { continuing business operations at the tolerable level }\end{array}$ \\
\hline Incident & $\begin{array}{l}\text { A situation that may occur and cause a disruption of the entity's operations, destruction, losses, emergency or business } \\
\text { crisis }\end{array}$ \\
\hline Principle 1 & $\begin{array}{l}\text { Business continuity management requirements apply to all actors of the financial sector and financial institutions. } \\
\text { The board of directors and top executives are totally responsible for business continuity management, unlike } \\
\text { management of other risks }\end{array}$ \\
\hline Principle 2 & $\begin{array}{l}\text { Entities shall have a sound assessment of threats and have a major operational disruption plan. The approach is not } \\
\text { common for may entities, but it is worth observing since instances of considerable operational disruptions become } \\
\text { more frequent }\end{array}$ \\
\hline Principle 3 & $\begin{array}{l}\text { Actors of the financial sector shall set up recovery goals in line with the potential risk of the actors in relation to } \\
\text { financial operations. Recovery goals are formulated consistently with the risk level, which may be associated with any } \\
\text { actor so to actually ensure the reasonable level of sustainability }\end{array}$ \\
\hline Principle 4 & $\begin{array}{l}\text { Business continuity plan shall address all aspects of internal and external communications in case of a big operational } \\
\text { disruption. It will help tackle the crisis and preserve public confidence }\end{array}$ \\
\hline Principle 5 & Particular cases of cross-border communications are reported in case of a big operational disruption \\
\hline Principle 6 & Business continuity plans shall be effective and constantly updated following regular tests \\
\hline Principle 7 & $\begin{array}{l}\text { Financial authorities should also check the business continuity management process as part of their duties and use the } \\
\text { results to evaluate actors of the financial market }\end{array}$ \\
\hline
\end{tabular}

Source: Rukovodyashchie printsipy obespecheniya nepreryvnosti biznesa. Rekomendatsii po nablyudeniyu za nepreryvnost'yu deyatel'nosti dlya sistemno znachimykh platezhnykh sistem [Guidelines for business continuity management. Recommendations for monitoring the going concern for systemically important payment systems (SIPS)].URL: http://www.cbr.ru/publ/Default.aspx?PrtID=prs\&code=78 (In Russ.)

\section{Table 3}

Requirements of Russian and international standards of accounting and auditing to ensuring the going concern principle by economic entities

\begin{tabular}{|c|c|c|}
\hline Regulation & Definition of continuity principle & $\begin{array}{l}\text { Requirements to evaluating } \\
\text { the reasonableness of the going concern } \\
\text { assumption }\end{array}$ \\
\hline $\begin{array}{l}\text { 1. IAS } 1 \text { Presentation of Financial Statements } \\
\text { [IAS } 1.25,1.26]^{*}\end{array}$ & $\begin{array}{l}\text { When preparing financial statements, } \\
\text { management shall make an assessment of an } \\
\text { entity's ability to continue as a going concern. } \\
\text { An entity shall prepare financial statements on } \\
\text { a going concern basis unless management } \\
\text { either intends to liquidate the entity or to cease } \\
\text { trading, or has no realistic alternative but to do } \\
\text { so }\end{array}$ & $\begin{array}{l}\text { In assessing whether the going concern } \\
\text { assumption is appropriate, management takes } \\
\text { into account all available information about } \\
\text { the future, which is at least, but is not limited to, } \\
\text { twelve months from the end of the reporting } \\
\text { period. The degree of consideration depends on } \\
\text { the facts in each case. When an entity has } \\
\text { a history of profitable operations and ready }\end{array}$ \\
\hline
\end{tabular}

Please cite this article as: Babicheva N.E., Lyubushin N.P., Kondrat'ev R.Yu. The Business Continuity Concept in the Assessment of Creditworthiness of Economic Agents. Digest Finance, 2018, vol. 23, iss. 1, pp. 3-15. https://doi.org/10.24891/df.23.1.3 


2.PBU 1/2008 Corporate Accounting Policies"

An entity will continue its operations in the foreseeable future and has no intentions and need to discontinue or considerable reduce its operations. Thus, liabilities will be performed in a due manner access to financial resources, the entity may reach a conclusion that the going concern basis of accounting is appropriate without detailed analysis. In other cases, management may need to consider a wide range of factors relating to current and expected profitability, debt repayment schedules and potential sources of replacement financing before it can satisfy itself that the going concern basis is appropriate If the financial reporting process is coupled with considerable uncertainty about events and conditions, which may raise significant doubts concerning the applicability of the going concern assumption, the entity shall indicate such uncertainty and explicitly describe the reason

Considering the available financial information, unless otherwise stated, there is an assumption based on a professional judgment that the entity will continue as a going concern indefinitely

The going concern principle allows for measurement of non-current assets as if they will be used in corporate operations, rather than sold.

Furthermore, the following aspects are determined:

- period of time, during which the entity is able to meet its obligations;

- information and analytical framework used to evaluate whether the entity is able to meet its obligations;

- the effect of subsequent events on the entity's ability to meet its obligations

4. Statement on Auditing Standards 1

Codification of Auditing Standards and

Procedures, Section 341, The Auditor's

Consideration of an Entity's Ability to Continue as a Going Concern (AU Section 341)

5. ISA 570, Going Concern
There is substantial evidence of the entity's ability to continue as a going concern for a reasonable period of time, not to exceed one year beyond the date of the financial statements being audited
Analytical procedures identify any indication of the entity's inability to continue to meet its obligations, use assets outside the ordinary course of business, restructure debts, and in case of externally forced revisions of its operations

Financial statements are prepared under the assumption that the entity is viewed as continuing in business for the foreseeable future

\section{When the use of the going concern assumption} is appropriate, assets and liabilities are recorded on the basis that the entity will be able to realize its assets and discharge its liabilities in the normal course of business

\footnotetext{
* Order of the RF Ministry of Finance On the Enactment of International Financial Reporting Standards and Clarifications of International Financial Reporting Standards in the Russian Federation and Abolishing of Some Other Orders (Certain Clauses) of the RF Ministry of Finance, of December 28, 2015 № $217 \mathrm{H}$

** Order of the RF Ministry of Finance On Approval of Accounting Principles (along with the Accounting Regulation - Corporate Accounting Policies (PBU 1/2008), Accounting Regulation - Changes in Estimates (PBU 21/2008), of October 6, 2008 № 106H (Edition of April 6, 2015).

${ }^{* * *}$ Statement on Auditing Standards 1 Codification of Auditing Standards and Procedures. URL: http://www.aicpa.org/research/standards/auditattest/downloadabledocuments/au-00341.pdf

${ }^{4 *}$ International Standard on Auditing 570 Going Concern. URL: http://www.ifac.org/system/files/downloads/a031-2010-iaasb-handbook-isa-570.pdf Source:Authoring
} 


\section{Table 4}

Disclosure of dynamic and static balance sheets

\begin{tabular}{|c|c|c|c|}
\hline Balance sheet type & Purpose & $\begin{array}{l}\text { Corporate property appraisal } \\
\text { approaches }\end{array}$ & $\begin{array}{l}\text { Recognition of accounts payable in } \\
\text { the balance sheet }\end{array}$ \\
\hline Dynamic & $\begin{array}{l}\text { Recognition of financial results from } \\
\text { perspectives of ideal assets and } \\
\text { liabilities to protect owners' interests }\end{array}$ & $\begin{array}{l}\text { Assessment of the existing capabilities } \\
\text { and financial results from the property } \\
\text { use by recognizing the property value } \\
\text { as needed to calculate the annual } \\
\text { profit under the going concern } \\
\text { assumption. The return on equity is } \\
\text { the key indicators of the efficient } \\
\text { property use }\end{array}$ & $\begin{array}{l}\text { The balance sheet presents only } \\
\text { actually received amount of debt (loan), } \\
\text { including interests accrued in the } \\
\text { current year for the use of borrowings }\end{array}$ \\
\hline Static & $\begin{array}{l}\text { Regular assessment of the property } \\
\text { status to protect creditors' interests. } \\
\text { Assurance of the sufficiency of } \\
\text { monetary proceeds from conditional } \\
\text { sale of assets to discharge liabilities to } \\
\text { creditors. } \\
\text { According to J. Richard, the static } \\
\text { balance sheet theory results from } \\
\text { understanding of a protracted period of } \\
\text { practical evaluation of entities' } \\
\text { financial position using the accounting } \\
\text { methodology, which is based on the } \\
\text { legislative culture of the Roman law. It } \\
\text { implies that the less frequent instances } \\
\text { of insolvency and bankruptcy, the } \\
\text { higher legal stability of civil turnover }\end{array}$ & $\begin{array}{l}\text { The precise definition of the property } \\
\text { value, i.e. the resource endowment of } \\
\text { an entity, through the discontinued } \\
\text { operation concept. Property shall be } \\
\text { stated at the price of possible sale as } \\
\text { of the balance sheet date. } \\
\text { Value of net assets is the key indicator } \\
\text { of solvency }\end{array}$ & $\begin{array}{l}\text { Voluntarily or coercively recognized } \\
\text { debt (loan) is recognized in the balance } \\
\text { sheet, including interests accrued for } \\
\text { the entire period of the loan. Liquidity } \\
\text { ratios are used for assessment } \\
\text { purposes }\end{array}$ \\
\hline
\end{tabular}

Source:Authoring, based on Zabbarova 0.A. Balansovedenie [Balance sheet studies]. Moscow, KnoRus Publ., 2007, 256 p.; [19, 20] 


\section{Figure 1}

Changes in and forecast of current liquidity ratio and net working capital

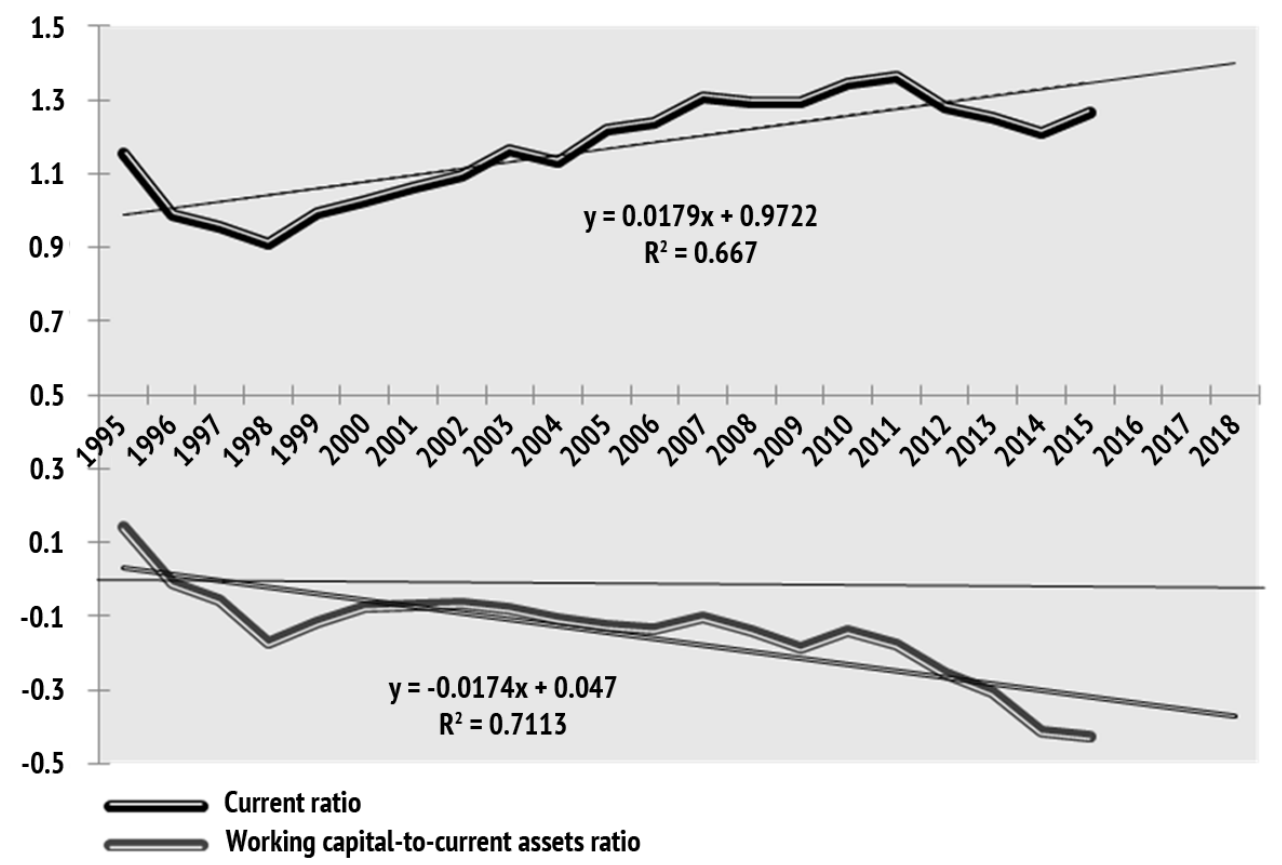

Source:Authoring, based on Rosstat data. URL: http://www.gks.ru/wps/wcm/connect/rosstat_main/rosstat/ru/statistics/finance/\#

\section{Acknowledgments}

The article was supported by the Russian Foundation for Basic Research, grant No. 16-06-00390.

The article was supported by the Publishing house FINANCE and CREDIT's Information center at the Voronezh State University.

\section{References}

1. Mendel'son L.A. Teoriya i istoriya ekonomicheskikh krizisov i tsiklov [The theory and the history of economic crises and cycles]. Moscow, Izdatel'stvo sotsial'no-ekonomicheskoi literatury Publ., 1959, 693 p.

2. Kovalev V.V. Finansovyi uchet i analiz: kontseptual'nye osnovy [Financial accounting and analysis: Conceptual framework]. Moscow, Finansy i Statistika Publ., 2004, 720 p.

3. Altman E.I. Financial Ratios, Discriminant Analysis and the Prediction of Corporate Bankruptcy. The Journal of Finance, 1968, vol. 23, iss. 4, pp. 589-609. URL: https://doi.org/10.1111/j.1540-6261.1968.tb00843.x

4. Çelik R., Bilen B., Bilen Ö. The Impacts of Changes in Macro-Economic Data on Net Working Capital: The Case of Turkey's Industrial Sector. Procedia Economics and Finance, 2016, vol. 38, pp. 122-134.

URL: https://doi.org/10.1016/S2212-5671(16)30184-8

5. Shevelev A.E. Kontseptsiya nepreryvnosti deyatel'nosti v bukhgalterskom uchete predpriyatiya v sovremennykh ekonomicheskikh usloviyakh: monografiya [The going concern concept in accounting records of the enterprise under modern economic conditions: a monograph]. Chelyabinsk, South Ural State University Publ., 2005,210 p.

6. Amanzholova B.A., Ovchinnikova N.N. [Going concern in financial statements and accounting policy: Forecasting the economic and social impact]. Ekonomicheskii analiz: teoriya i praktika = Economic Analysis: Theory and Practice, 2015, vol. 14, iss. 46, pp. 44-55. URL: https://cyberleninka.ru/article/v/printsip-nepreryvnostideyatelnosti-v-buhgalterskoy-otchetnosti-i-uchetnoy-politike-organizatsiy-prognozirovanie-ekonomicheskih-i (In Russ.) 
7. Endovitskii D.A., Babushkin V.A, Baturina N.A. Analiz investitsionnoi privlekatel'nosti organizatsii [Analysis of investment attractiveness of the organization]. Moscow, KnoRus Publ., 2010, 376 p.

8. Lyubushin N.P., Babicheva N.E. [Analyzing the techniques to evaluate financial condition of the organization]. Ekonomicheskii analiz: teoriya i praktika = Economic Analysis: Theory and Practice, 2006, no. 22, pp. 2-7. (In Russ.)

9. Edronova V.N., Khasyanova S.Yu. [Foreign and domestic approaches to defining the creditworthiness of borrowers]. Finansy $i$ kredit =Finance and Credit, 2002, no. 10, pp. 25-27. (In Russ.)

10. Kleiner G.B. Razvitie teorii ekonomicheskikh sistem i ee primenenie v korporativnom i strategicheskom upravlenii [Development of the theory of economic systems and its application in corporate and strategic management]. Moscow, CEMI RAS Publ., 2010, 59 p.

11. Cordoş George-Silviu, Fulop Melinda-Timea. New Audit Reporting Challenges: Auditing the Going Concern Basis of Accounting. Procedia Economics and Finance, 2015, vol. 32, pp. 216-224. URL: https://doi.org/10.1016/S2212-5671(15)01385-4

12. Provasi R., Riva P. Assessment of Going Concern for the Italian Listed Companies: An Empirical Study. URL: https://www.questia.com/library/journal/1P3-3311016301/assessment-of-going-concern-for-the-italianlisted

13. Dănescu T., Mărginean R. The Evaluation of the Going Principle through the Altman Pattern - Case Study. Procedia Economics and Finance, 2015, vol. 32, pp. 1667-1674. URL: https://doi.org/10.1016/S2212-5671(15)01493-8

14. Robu I.B., Balan C.B., Jaba E. The Estimation of the Going Concern Ability of Quoted Companies, Using Duration Model. Procedia - Social and Behavioral Sciences, 2012, vol. 62, pp. 876-880. URL: https://doi.org/10.1016/j.sbspro.2012.09.147

15. Dmitrenko I.N., Belousova I.N. [The evolution of conceptual approach to going concern assumption]. Mezhdunarodnyi bukhgalterskii uchet = International Accounting, 2007, no. 10, pp. 34-38; no. 11, pp. 49-54. URL: https://cyberleninka.ru/article/v/evolyutsiya-kontseptualnogo-podhoda-k-dopuscheniyu-nepreryvnostideyatelnosti-subektov-hozyaystvovaniya-1 (In Russ.)

16. Baetge J. Balansovedenie: monografiya [Bilanzen]. Moscow, Bukhgalterskii uchet Publ., 2000, 411 p.

17. Shilova, L.F., Mirgorodskaya M.G. [The system of principles, its development based on the concepts of accounting study and application in modern conditions]. Innovatsionnoe razvitie ekonomiki = Innovative Development of Economy, 2013, no. 4-5, pp. 230-237. (In Russ.)

18. Doronina F.Kh. [The principle of continuity in international and national systems of accounting and reporting]. Vestnik Moskovskogo universiteta imeni S.Yu. Vitte. Ser. 1: Ekonomika i upravlenie, 2015, no. 1, pp. 107-113. (In Russ.) URL: http://www.muiv.ru/vestnik/pdf/eu/eu_2015_1_107-113.pdf

19. Sokolov Ya.V. Osnovy teorii bukhgalterskogo ucheta: monografiya [Fundamentals of the accounting theory]. Moscow, Finansy i Statistika Publ., 2003, 496 p.

20. Predeus N.V. [Theoretical analysis of the concepts of static and dynamic accounting]. Mezhdunarodnyi bukhgalterskii uchet = International Accounting, 2012, vol. 15, iss. 15, pp. 13-25. (In Russ.)

21. Richard J. Bukhgalterskii uchet: teoriya i praktika [Accounting: Theory and practice]. Moscow, Finansy i Statistika Publ., 2000, 160 p.

\section{Conflict-of-interest notification}

We, the authors of this article, bindingly and explicitly declare of the partial and total lack of actual or potential conflict of interest with any other third party whatsoever, which may arise as a result of the publication of this article. This statement relates to the study, data collection and interpretation, writing and preparation of the article, and the decision to submit the manuscript for publication. 